\title{
Processing, Cryopreserving and Controlling the Quality of HSCs
}

\author{
Patrick Wuchter
}

\subsection{Assessment of HSCs by Measuring CD34 and the Presence of Other Cell Subsets}

The efficiency of an autologous, as well as an allogeneic, HSCs graft is mainly determined by the number of $\mathrm{CD} 34^{+}$cells present. The dose of transplanted $\mathrm{CD}^{+} 4^{+}$cells per $\mathrm{kg}$ body weight (BW) determines the kinetics of the neutrophil and platelet engraftment after auto-HSCT (Weaver et al. 1995). The measurement of CD34+ cells by flow cytometry is, therefore, an important method to assess the graft quantity.

The minimal number of $\mathrm{CD}^{+} 4^{+}$cells for an autologous transplant is $\geq 2.0 \times 10^{6} \mathrm{CD}^{+} 4^{+}$cells/ $\mathrm{kg} \mathrm{BW}$. Transplants below this threshold should only be used in cases where no additional stem cell collection is feasible and there is a vital indication for the autologous stem cell transplantation. Most transplant centres regard a cell dose of 2.5-6 $\times 10^{6} \mathrm{CD} 34^{+}$cells $/ \mathrm{kg} \mathrm{BW}$ as optimal, based on published clinical data (Duong et al. 2014; Perez-Simon et al. 1999; Giralt et al. 2014; Lisenko et al. 2017b; Mohty et al. 2014). For an allo-HSCT, a cell dose of $\geq 4.0 \times 10^{6} \mathrm{CD} 34^{+}$cells/ $\mathrm{kg} \mathrm{BW}$ is regarded as adequate.

\footnotetext{
P. Wuchter $(\bowtie)$

Institute of Transfusion Medicine and Immunology,

German Red Cross Blood Service Baden-

Württemberg - Hessen, Medical Faculty Mannheim,

Heidelberg University, Mannheim, Germany

e-mail: Patrick.Wuchter@medma.uni-heidelberg.de
}

In the autologous setting, it has been speculated that the quality of $\mathrm{CD} 34^{+}$cells from poor mobilizers may be inferior. However, studies have found that the proportions of primitive and quiescent $\mathrm{CD} 34^{+}$subsets were comparable across mobilization groups (Jiang et al. 2012), and leukocyte and platelet recovery after transplantation was not different (Wuchter et al. 2010).

The application of plerixafor in order to overcome insufficient HSCs mobilization not only increases the number of $\mathrm{CD} 34^{+}$cells but also the proportion of more primitive HSCs subsets, the absolute lymphocyte count and the numbers of lymphocytes in various subsets $\left(\mathrm{CD} 19^{+}\right.$cells, $\mathrm{CD}^{+}$ cells, T-cells and NK-cells) in the autograft (Fruehauf et al. 2009; Taubert et al. 2011; Varmavuo et al. 2013). However, these variances do not translate into relevant clinical differences regarding haematopoietic recovery. Taken together, the graft quality from poor mobilizers can be regarded equivalent compared to that from good mobilizers, regardless of the use of plerixafor.

It was further speculated that the composition of cellular subsets in the transplant may have an influence on the haematopoietic reconstitution. However, based on the currently published data, no final conclusion can be drawn, and further investigations are warranted to determine the potential effects of autograft cell subsets on the patients' clinical outcomes. As delineated in an EBMT position statement from 2014, determination of cell subsets other than $\mathrm{CD} 34^{+}$cells is not routinely performed in clinical practice but only 
in clinical trials (Mohty et al. 2014). Accordingly, assessment of tumour cell contamination is usually not part of the clinical routine but can be of interest in clinical trials.

\subsection{HSCs Cryopreservation}

HSCs should be processed and stored in accordance with the respective Medical Council, responsible local and overarching authorities as well as scientific society's guidelines (e.g. EU: Guideline 2004/23/EG and 2006/17/EG, EU-GMP-Guideline).

If necessary, collected cells can be stored for a maximum of up to $72 \mathrm{~h}$ at $2-6{ }^{\circ} \mathrm{C}$ before cryopreservation. However, cryopreservation within $48 \mathrm{~h}$ or less is recommended to maintain an optimal viability of the cells. In the case of storage for $>24 \mathrm{~h}$ prior to cryopreservation, the maximum nucleated cell (NC) concentration should not exceed $2 \times 10^{8} / \mathrm{mL}$.

For cryopreservation, a number of different protocols are used worldwide. Usually, the maximum accepted NC concentration is $\leq 4 \times 10^{8} / \mathrm{mL}$. If necessary, PBSC products can be diluted with autologous plasma or commercial resuspension medium. Increasing the cell concentration by volume depletion minimizes the number of cryostored bags needed, but the upper limit of the NC concentration needs to be considered. The final product includes 5-10\% dimethyl sulfoxide (DMSO) as a cryoprotectant and $0.05-0.25 \mathrm{~mL}$ of ACD-A stabilizer solution per $\mathrm{ml}$ of transplant. Freezing at a controlled rate of $1-2{ }^{\circ} \mathrm{C}$ per minute is recommended. Cells need to be stored in vapour phase nitrogen at a temperature of $\leq-140{ }^{\circ} \mathrm{C}$. Cross-contamination while preparing and storing the cells must be prevented by taking appropriate measures.

At the time of auto-HSCT, cryopreserved bags must be thawed at the site of transplantation, and PBSCs should be reinfused within a maximum time span of 10-20 min of thawing using standard transfusion filters in order to minimize the detrimental effect of DMSO upon HSCs. Previous washing for purposes of DMSO depletion is not routinely performed, as the loss and damage of HSCs are regarded as too high.
Several studies demonstrated that under these storage conditions, $\mathrm{CD} 34^{+} \mathrm{HSCs}$ remained viable for up to 19 years (Fernyhough et al. 2013; McCullough et al. 2010; Spurr et al. 2002). In addition, a recent study demonstrated that the duration of cryostorage of the transplant had no impact on the haematologic reconstitution after transplantation (Lisenko et al. 2017a).

\subsection{HSCs Quality Assessment}

HSCs product quality assessment needs to be performed at several time points during cell processing and storage. Volume measurement, enumeration of $\mathrm{NC}$ and red blood cells and flow cytometry-based $\mathrm{CD} 4^{+}$cell quantification should be performed directly after PBSC collection in accordance with the Stem Cell Enumeration Committee Guidelines of the International Society of Hematotherapy and Graft Engineering (ISHAGE) (Sutherland et al. 1996). A validated protocol and external quality control (e.g. the round robin test) is strongly recommended (Whitby et al. 2012).

Shortly before freezing, microbiological culture samples must be obtained. NC enumeration and $\mathrm{NC}$ viability measurement (e.g. by staining with trypan blue, 7-aminoactinomycin D [7-AAD] or propidium iodide) should be performed from aliquots of the final cell product after freezing and thawing. This viability testing is only valid for a defined and limited time span, often 2-5 years based on local guidelines, before it needs to be repeated prior to transplantation. As a result, a sufficient number of reference samples should be prepared for each HSCs product (the recommended minimum number is 3 ).

Target values need to be defined for the final product, mostly in accordance with local authorities. In most transplant centres in Europe, the following criteria are mandatory (together with additional criteria) for the release of an autologous transplant: NC concentration $\leq 4 \times 10^{8} / \mathrm{mL}$, $\mathrm{CD}^{2} 4^{+}$cell number $\geq 2 \times 10^{6} / \mathrm{kg}$ BW, red blood concentration $\leq 0.1 \mathrm{~mL}$ per $\mathrm{mL}$ of transplant, no microbial growth and minimum NC viability of $>50 \%$ after freezing and thawing. 


\subsection{Collection of Reference (Retention) Samples for Quality Control}

Reference samples for quality control must be taken and stored from the cell product. These samples allow the proof of quality and potency of the transplant in terms of sterility, purity and viability of the cells. In the case of an allo-HSCT, reference samples may also need to be collected from the donor, depending on the respective local legal situation, to allow for a retrospective analysis in terms of serological testing.

Reference samples are prepared in parallel with the cell product and stored under the same cryoconditions until they are analysed. As a release criterion for an autologous stem cell transplant, a reference sample should be cryopreserved for $>24 \mathrm{~h}$ under the identical conditions as the cell product before the viability of $\mathrm{CD}^{+} 4^{+}$ $\mathrm{CD} 45^{+}$cells is analysed. Performing a clonogenic assay (e.g. colony-forming assay) from the reference samples can assess the haematopoietic potency of the cells. However, this is not regarded as a release criterion but should be performed for process validation or in the case of prolonged cryostorage of a transplant ( $>2-5$ years).

The final cell product must be labelled in accordance with respective legal requirements. In order to transport cryopreserved HSCs products, a validated shipping container is required, preferably with continuous temperature monitoring. The treating physician is responsible for application of the HSCs transplant after evaluating its integrity and the accompanying documents.

\section{Key Points}

- Minimal number of $\mathrm{CD}^{+} 4^{+}$cells is $\geq 2.0 \times 10^{6} / \mathrm{kg}$ BW for an auto-HSCT and $\geq 4.0 \times 10^{6} / \mathrm{kg} \mathrm{BW}$ for an Allo-HSCT.

- Determination of cell subsets other than $\mathrm{CD} 34^{+}$is not routinely required.

- Cryopreservation needs to be performed within $72 \mathrm{~h}$, preferably $<48 \mathrm{~h}$.
- The maximum NC concentration in the cryostored transplant should be $\leq 4 \times 10^{8} / \mathrm{mL}$.

- The final product includes 5-10\% DMSO as a cryoprotectant and 0.05$0.25 \mathrm{~mL}$ of ACD-A stabilizer solution per ml of transplant.

- Freezing at a controlled rate of $1-2{ }^{\circ} \mathrm{C}$ per minute is recommended, and cells need to be stored in vapour phase nitrogen at a temperature of $\leq-140{ }^{\circ} \mathrm{C}$.

- $\mathrm{NC}$ viability should be $>50 \%$ after freezing and thawing.

- At the time of ABSCT, cryopreserved bags must be thawed and reinfused within a maximum of 10-20 min of thawing.

- Reference samples for quality control must be prepared and cryostored in parallel and under identical conditions as the cell product.

\section{References}

Duong HK, Savani BN, Copelan E, et al. Peripheral blood progenitor cell mobilization for autologous and allogeneic hematopoietic cell transplantation: guidelines from the American Society for Blood and Marrow Transplantation. Biol Blood Marrow Transplant. 2014;20:1262-73.

Fernyhough LJ, Buchan VA, McArthur LT, Hock BD. Relative recovery of haematopoietic stem cell products after cryogenic storage of up to 19 years. Bone Marrow Transplant. 2013;48:32-5.

Fruehauf S, Veldwijk MR, Seeger T, et al. A combination of granulocyte-colony-stimulating factor (G-CSF) and plerixafor mobilizes more primitive peripheral blood progenitor cells than G-CSF alone: results of a European phase II study. Cytotherapy. 2009;11:992-1001.

Giralt S, Costa L, Schriber J, et al. Optimizing autologous stem cell mobilization strategies to improve patient outcomes: consensus guidelines and recommendations. Biol Blood Marrow Transplant. 2014;20:295-308.

Guidelines 2004/23/EG des Europäischen Parlaments und des Rates vom 31. März 2004 zur Festlegung von Qualitäts- und Sicherheitsstandards für die Spende, Beschaffung, Testung, Verarbeitung, Konservierung, Lagerung und Verteilung von menschlichen Geweben und Zellen. Amtsblatt der Europäischen Union. 
Guidelines 2006/17/EG der Kommission vom 8. Februar 2006 zur Durchführung der Richtlinie 2004/23/EG des Europäischen Parlaments und des Rates hinsichtlich technischer Vorschriften für die Spende, Beschaffung und Testung von menschlichen Geweben und Zellen. Amtsblatt der Europäischen Union.

Guidelines EU-Leitfaden der Guten Herstellungspraxis Humanarzneimittel und Tierarzneimittel (EU-GMP). Europäische Kommission: EudraLex;4.

Jiang L, Malik S, Litzow M, et al. Hematopoietic stem cells from poor and good mobilizers are qualitatively equivalent. Transfusion. 2012;52:542-8.

Lisenko K, Pavel P, Kriegsmann M, et al. Storage duration of autologous stem cell preparations has no impact on hematopoietic recovery after transplantation. Biol Blood Marrow Transplant. 2017a;23:684-90.

Lisenko K, Wuchter P, Hansberg M, et al. Comparison of different stem cell mobilization regimen in $\mathrm{AL}$ amyloidosis patients. Biol Blood Marrow Transplant. 2017b;23:1870-8.

McCullough J, Haley R, Clay M, et al. Long-term storage of peripheral blood stem cells frozen and stored with a conventional liquid nitrogen technique compared with cells frozen and stored in a mechanical freezer. Transfusion. 2010;50:808-19.

Mohty M, Hubel K, Kroger N, et al. Autologous haematopoietic stem cell mobilisation in multiple myeloma and lymphoma patients: a position statement from the European Group for Blood and Marrow Transplantation. Bone Marrow Transplant. 2014;49:865-72.

Perez-Simon JA, Martin A, Caballero D, et al. Clinical significance of CD34+ cell dose in long-term engraftment following autologous peripheral blood stem cell transplantation. Bone Marrow Transplant. 1999;24:1279-83.

Spurr EE, Wiggins NE, Marsden KA, et al. Cryopreserved human haematopoietic stem cells retain engraftment potential after extended (5-14 years) cryostorage. Cryobiology. 2002;44:210-7.

Sutherland DR, Anderson L, Keeney M, Nayar R, ChinYee I. The ISHAGE guidelines for CD34+ cell determination by flow cytometry. International Society of Hematotherapy and Graft Engineering. J Hematother. 1996;5:213-26.

Taubert I, Saffrich R, Zepeda-Moreno A, et al. Characterization of hematopoietic stem cell subsets from patients with multiple myeloma after mobilization with plerixafor. Cytotherapy. 2011;13:459-66.

Varmavuo V, Mantymaa P, Silvennoinen R, et al. CD34+ cell subclasses and lymphocyte subsets in blood grafts collected after various mobilization methods in myeloma patients. Transfusion. 2013;53:1024-32.

Weaver CH, Hazelton B, Birch R, et al. An analysis of engraftment kinetics as a function of the CD34 content of peripheral blood progenitor cell collections in 692 patients after the administration of myeloablative chemotherapy. Blood. 1995;86:3961-9.

Whitby A, Whitby L, Fletcher M, et al. ISHAGE protocol: are we doing it correctly? Cytometry B Clin Cytom. 2012;82:9-17.

Wuchter P, Ran D, Bruckner T, et al. Poor mobilization of hematopoietic stem cells-definitions, incidence, risk factors, and impact on outcome of autologous transplantation. Biol Blood Marrow Transplant. 2010;16:490-9.

Open Access This chapter is licensed under the terms of the Creative Commons Attribution 4.0 International License (http://creativecommons.org/licenses/by/4.0/), which permits use, sharing, adaptation, distribution and reproduction in any medium or format, as long as you give appropriate credit to the original author(s) and the source, provide a link to the Creative Commons license and indicate if changes were made.

The images or other third party material in this chapter are included in the chapter's Creative Commons license, unless indicated otherwise in a credit line to the material. If material is not included in the chapter's Creative Commons license and your intended use is not permitted by statutory regulation or exceeds the permitted use, you will need to obtain permission directly from the copyright holder. 